- Describes a unique archaeological object.

- Shows evidence of technological innovation in the early years of professional dentistry.

- Demonstrates that dental history can contribute to the interpretation of social history.

\title{
Archaeological evidence for dental innovation: an eighteenth century porcelain dental prosthesis belonging to Archbishop Arthur Richard Dillon
}

\author{
N. Powers ${ }^{1}$
}

During archaeological investigation by Gifford of St Pancras Old Church burial ground, on the eastern edge of Somers Town, London, in advance of construction of the new London terminus for the Channel Tunnel Rail Link, a full porcelain denture was discovered. The high quality porcelain dentures, manufactured in the late eighteenth century French style, may have been brought with their owner, Archbishop Arthur Richard Dillon, on his journey into exile. There is evidence of prolonged use, not only for cosmetic or vocal functions but also in mastication. The dentures are unique archaeological artefacts and represent a pivotal time in dental history, with the adoption of new materials and methods of manufacture. They reflect a period of significant social and economic change for the upper echelons of French society. This paper outlines the development of porcelain dentures, discusses the prosthesis, their owner, and a possible provenance.

The extension of the burial ground of St Pancras Old Church (1793-1854) was partially cleared by an exhumation contractor during 2001, in advance of construction of the London terminus for the Channel Tunnel Rail Link. As the archaeological organisation appointed by Rail Link Engineering, Gifford lead a large scale archaeological watching brief on the clearance works. Controlled stratigraphic excavation was conducted in a small sample area. Over 700 individuals were osteologically recorded. A wealth of pathological and demographic data was collected. A significant French émigrés presence has been established, of which Arthur Dillon, Archbishop of Narbonne and Primate of Languedoc, is the most eminent member.

${ }^{1}$ Museum of London Archaeology Service, Mortimer Wheeler House, 46 Eagle Wharf Road, London, N1 7ED Correspondence to: Natasha Powers

Email:npowers@museumoflondon.org.uk

\section{Refereed Paper}

Accepted 8 March 2006

DOI: $10.1038 /$ sj.bdj.4814117

๑) British Dental Journal 2006; 201: 459-463
DENTAL HYGIENE AND TREATMENT IN THE EIGHTEENTH CENTURY

Archaeological excavations have shown poor dental health amongst London populations of this time. At least $87 \%$ of the sample interred in Spitalfields crypt, east London had carious teeth with 96\% of the oldest adults (56+ years) affected. ${ }^{1}$ Refined sugars and finely milled carbohydrates were widely accessible and contributed to poor dental health. However, toothpowders and dentifrices were available. The notable French dentiste Pierre Fauchard recommended one's own urine as a tooth cleaner, ${ }^{2,3}$ while Lord Chesterfield extolled the virtues of washing the teeth and mouth with a soft sponge and water rather than 'any hard substance ... which always rubs away the gums and destroys the varnish of the teeth. ${ }^{3}$ Bristle and gold toothbrushes were available but do not appear to have been in widespread use, ${ }^{3,4}$ while fans and perfumes disguised the appearance and smell of rotting teeth. ${ }^{5}$ Vivid accounts exist of ulcers, fevers and even jaundice as the result of carious teeth and rotting ivory dentures. ${ }^{6}$ The London Bills of Mortality refer to 'teeth' as a cause of death (possibly septicaemia) in 7\% of the population in the seventeenth century, falling to $2 \%$ during the eighteenth century. ${ }^{4}$

By the late eighteenth century, all socio-economic groups had access to a toothdrawer, but only the wealthy could afford to have extracted teeth replaced. Dentistes became increasingly fashionable during the second half of the eighteenth century, the term associated with the French in particular. ${ }^{3,7}$ Dentists did not manufacture all prostheses: precious metals might be manipulated by goldsmiths or watchsmiths, and organic materials by ivory turners. ${ }^{8}$ Similarly, many dentists advertised themselves as having multiple skills, such as chiropody or surgery. ${ }^{9}$ False teeth were in such demand that they could be ordered by post. ${ }^{3}$

\section{ARCHBISHOP DILLON}

Arthur Richard Dillon, Archbishop of Narbonne, was born in St-Germainen-Laye, Paris in 1721. From General of Pontoise, to Bishop of Évreux, he became Archbishop of Narbonne and Primate of the Gauls in 1763. Serving as President of the General Assembly of the clergy of France in 1775 and 1785, he was 


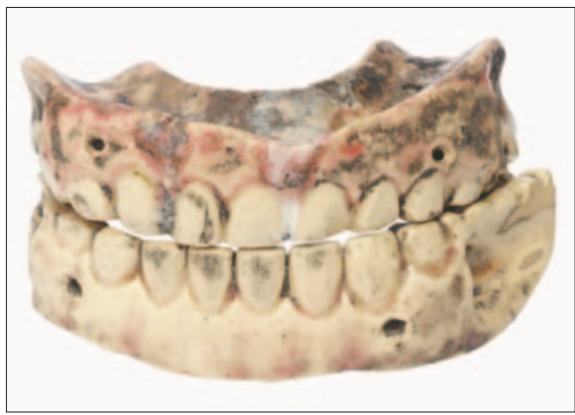

Fig. 1 Anterior view of the porcelain dentures (photograph A. Chopping, MoLAS)

a member of the first and second Assemblées des Notables (1787 and 1788). He was an extremely wealthy man with an annual income of 360,000 livres. ${ }^{10,11}$ Described as one of the last of the old regime, he was 'witty, self indulgent, inflexible on the matter of social class prejudice ... with courtly readiness of tongue..11 He escaped the guillotine and, in 1791, emigrated to England (via Koblenz and Prussia), settling in London. He was the highest ranking of around 8,000 clergy who fled France at this time. ${ }^{12,13}$

In London, he was financially supported by his nephew, Viscount Dillon, the émigré community and a monthly income of $£ 15$ from the British Government. He lived well, although in reduced circumstances, in a property large enough for a further six bishops, and became a vocal member of the exiled clergy. He died in July 1806, aged 85 years, at his house in George Street, Portman Square, and was buried at St Pancras. In France he left debts of $1,800,000$ livres. ${ }^{14,15}$

\section{THE ARCHAEOLOGICAL EVIDENCE}

The skeletal remains of Archbishop Dillon were in moderately good condition. He was edentulous. Damage to the facial bones prevented measurement, but data from the mandible indicated there was slight asymmetry in height of the molar region: the right side was $26 \mathrm{~mm}$ in height, the left $18 \mathrm{~mm}$. This is likely to relate to resorption and remodelling of the bone following tooth loss. Pathological changes in the skeleton indicate osteoarthritis and (age-related) spinal joint disease. ${ }^{16}$ The bishop also suffered from diffuse idiopathic skeletal hyperostosis, reportedly correlated with a rich diet and late-onset diabetes. ${ }^{17}$ Small circular, sharp-edged lesions on the first metatarsals were consistent with possible gout. ${ }^{18}$

\section{THE DENTURES}

The development of porcelain teeth

Pierre Fauchard published his treatise Le chirurgien dentiste in 1728, establishing France's position as leader in dental technology. ${ }^{5}$ In 1774 pharmacist Alexis
Duchateau began experiments with mineral paste teeth as his own ivory dentures were causing discomfort. Working in the Guerhard factory, St-Germain-en-Laye (coincidentally, where Dillon was born), Duchateau invented a paste that vitrified at a low temperature to achieve a good fit without shrinkage on firing. He took the process to the Royal Academy of Surgeons in Paris in 1776, receiving an honourable mention. ${ }^{5}$ He joined forces with Nicholas Dubois De Chemant in 1779. De Chemant experimented with new mixtures, glazes and springs, publishing his results in $1788,,^{5,19}$ and installed a small furnace at the Sèvres factory, specially adapted for firing the teeth. He used Josiah Wedgwood's pyrometer noting that the final paste required a temperature of 12-25 degrees as opposed to the 72-75 degrees previously needed. ${ }^{20}$ De Chemant obtained a royal patent for ' $m$ ineral paste teeth' from Louis XVI in 1789. Beeswax, and later plaster, was used to take moulds for fitting. ${ }^{21}$ In 1792 he left France for England, where porcelain for vessels had only been relatively recently introduced. ${ }^{22}$ De Chemant patented his method in London in 1791, publishing his dissertation (little more than a lengthy advert) in 1804. The patent for 'a composition for the purpose of making of artificial teeth, either single, double or in rows, or in complete setts [sic] and also springs for fastening or affixing the same in a more easy and effectual manner that any hitherto discovered ${ }^{23}$ outlines the proportions of fine white sand, alicant barilla (obtained by burning kelp), ${ }^{24}$ marl and clear water required for the finest porcelain, and how to make inferior quality teeth using earthenware clays or Limoges Kaolin. Colour was added using Prussian blue 'saffron of mars' and 'Naples yellow'. De Chemant advocated taking a cast from a beeswax form using plaster 'as is mixed for cornice moulds'. Holes were bored for the fixings before the paste was completely dried. ${ }^{23}$

In the 1790s porcelain dentures were a great success in England. De Chemant was highly sought after, obtaining testimonials from 'celebrity' patients including Edward Jenner. ${ }^{22}$ He was Dr. John Hunter's dentist, ${ }^{25}$ and one French Comte even wrote a poem extolling the dentures' virtues. De Chemant claimed that by 1804 , there were 12,000 sets of his dentures in use. ${ }^{5}$ The mineral paste was also used for cosmetic reconstruction of the palate and gums. ${ }^{6}$

Porcelain dentures were heavy and it was acknowledged that they could crack, resulting in a grinding sound when chewing. ${ }^{21}$ Letters show customers were returning the artificial teeth for adjustment. ${ }^{24}$ One of De Chemant's opponents in France, Dubois-Foucou, went so far as to warn the public that only those who were not afraid of the shock that seeing a pair of De Chemant's dentures might cause should obtain any, that they were brittle and dangerous. ${ }^{26}$ Caricatured by Rowlandson in $1811,{ }^{7}$ by 1814 they had fallen out of fashion due to their unnatural appearance and poor quality copies that fitted badly. ${ }^{5}$ Human teeth set in precious metal became the favoured choice once more.

Contrary to other authors who indicate he died in 1824 , Kurdyk ${ }^{26,27}$ reports that De Chemant returned to Paris, resuming dealings with Sèvres in 1825 , leaving the London business in control of his brotherin-law. Others then developed the technology further, with individual teeth set into other surrounds or fixed to the root of an existing tooth. ${ }^{28}$

Hargreaves $^{8}$ doubts that the French Revolution was the vehicle for an influx of dentists to England at this time, stating De Chemant left because of disagreements over his patent. Duchateau praised him in a pamphlet of 1791 but later launched a legal bid to have De Chemant's claims of invention refuted. ${ }^{19}$ De Chemant had been publicly branded a counterfeiter by royal dentist Dubois-Foucou in 1788 , though other prominent men of medicine supported him. Surely, the destruction of his furnace at the Sèvres factory by order of the Civil List Superintendent de Laporte and subsequent removal of his access to porcelain paste, ${ }^{26,27}$ must have been the catalyst for emigration? Many of the Dentistes' clientele would also have fled, so the new client-base in London, and the changing fashions it brought with it, would have made the move economically viable.

\section{Description of the teeth and jaws}

A full upper and lower denture of porcelain was discovered with the skeletal remains (Fig. 1). The interior surface of the teeth could be seen from its irregular profile to have been specifically moulded for this individual. Observations of the dentures in situ support this theory as the dentures proved a snug fit to the alveolar bone.

The maxillary prosthesis measured a maximum of $58 \mathrm{~mm}$ (buccal to buccal) by $40 \mathrm{~mm}$ (anterior to posterior), with a maximum height of $16 \mathrm{~mm}$ on the buccal edge of the left molar region and a superior width of $19 \mathrm{~mm}$. The sides of the denture were almost parallel reflecting the narrow arch of the upper set. The mandibular piece measured $37 \mathrm{~mm}$ from the centre of the anterior teeth to the left extremity and $34 \mathrm{~mm}$ on the right side. 


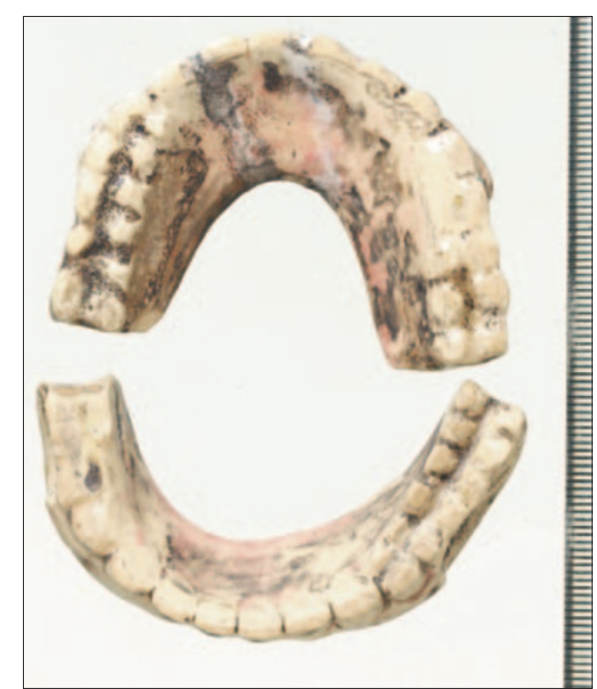

Fig. 2 Occlusal wear and over-glazing indicating repair (photograph A. Chopping, MoLAS)

The right distal surface was concave to allow space for a molar tooth, with a small area of wear reflecting the surface anatomy of the mesial tooth crown. The prosthesis was taller on its left side (17 mm versus $15 \mathrm{~mm}$ ), reflecting differential alveolar resorption. The maximum anterior width was $12 \mathrm{~mm}$. There was a gentler curve than in the upper set, forming a gradual arc. The eight anterior teeth in both upper and lower sets were realistically modelled, while the molars were more roughly represented. The lingual surfaces of the teeth were undifferentiated and, in the upper set blended smoothly into the palatal surface of the denture.

The teeth themselves were ivory in colour, while the gums and palate had traces of deep pink glaze. This colouration was more apparent on the upper set than the lower, where it only appeared in the slightly depressed areas of the gum. Black concretions on the palatal, gingival and buccal surfaces are thought to be the product of the interaction of the burial environment with underlying calculus deposits.

The occlusal surfaces were worn, with no glaze remaining on the upper denture. This wear was asymmetrical, suggesting a mastication pattern that favoured the left side. Two areas of overglazing could be seen in the upper denture along the midline and distal to the right second incisor. Both had resulted in pigment filling the inter-dental space. This glaze was markedly whiter in colour and corresponded to two parallel cracks within the denture: this represents repairs. The central break was unstained, the other black. It is possible that the central repair was more recent and had not suffered the same degree of calculus formation (Fig. 2).

Four smooth-sided circular holes located at the 'roots' of the canine teeth would have contained the ends of springs, held in place by a rivet set through a smaller, lateral hole. ${ }^{29}$ A single gold, coiled spring c.55 $\mathrm{mm}$ in length and 3 $\mathrm{mm}$ in diameter, still slightly bent, was recovered. Distal to the attachment area, below the occlusal surfaces on the buccal face in the molar region, ran a horizontal, concave depression, presumably to provide a comfortable fit and for ease of use. De Chemant was known to carry out large-scale extraction of carious or unstable teeth prior to the manufacture of a denture, ${ }^{5}$ and Whittaker ${ }^{30}$ also discussed the possibility of the deliberate extraction of teeth in advance of fitting prostheses. The remodelled nature of the alveolar bone of Archbishop Dillon prevented observations.

\section{Form and function}

'It was the ability of [sic] produce dentures which identified the true dentist and separated him from the common tooth drawer. ${ }^{31}$ Pierre Fauchard had quickly realised that without a palate piece all false teeth ended up slipping, and remarked that full dentures could only be for cosmetic purposes and to aid in pronunciation. ${ }^{21}$ Woodforde ${ }^{5}$ notes that full dentures for the maxilla were rare, as functional sets were so difficult to achieve successfully. An article had been published warning that porcelain was only suitable for lower dentures, ${ }^{26}$ and the Archbishop was relatively bold in purchasing a full set. Woodforde ${ }^{25}$ states that late Georgian false teeth were so strange in their appearance that their acquisition would have been remarked upon. No reference is made in any of the documents referring to the archbishop's health.

Lady Jerningham described Dillon (her uncle) as an excellent speaker, with style and presence. ${ }^{15}$ Dentures would have proved useful to a professional orator such as he. De Chemant published a letter from a satisfied customer of Great Russell Street, who stated his dentures had 'restored the voice of a person totally unable to articulate; the whole powers of mastication are likewise surprisingly recovered'. ${ }^{6}$ Occlusal wear suggests Dillon's dentures were not simply cosmetic, but aided chewing. It also appears from the wear pattern that the denture was well enough fitting to prevent the increased rotation of the mandible seen in edentulous individuals. ${ }^{32}$

Coiled springs were adopted in the mideighteenth century where flat metal had previously been used. ${ }^{5}$ Bent backwards into a ' $C$ ' shape within the buccal area, the gold springs provided a constant force pressing the dentures into the gums, as is demonstrated in contemporary works. ${ }^{6}$ This helped the dentures to stay in place, but could require considerable effort to close the mouth once it was opened. Strong buccal muscles would also have been necessary to prevent transverse slipping during use. ${ }^{5,25}$ Springs themselves could cause injury if they changed from a ' $C$ ' to and ' $S$ ' shape, but they prevented many of the problems resulting from resorption of the alveolar bone and gum shrinkage. $^{3}$

The lack of definition on the denture is comparable with other examples. ${ }^{32}$ Porcelain teeth were not fully separated to create extra strength. ${ }^{25}$ Traces of deep pink glaze only appeared in the slightly depressed areas of the gum, suggesting that rubbing against the lower lip removed the glaze over time and implying prolonged use. The grinding surfaces were known to lose their glaze and Dillon's set are no exception. ${ }^{25}$ Given contemporary accounts of porcelain dentures cracking during use, ${ }^{25}$ it is reasonable to conclude that breaks in the maxillary prosthesis represent fracture during use. All indicate that this denture had been in use for some considerable time and this is supported by the discrepancy between the shape of the denture (which allowed space for a remaining molar tooth) and the edentulous mandible of the deceased. A good set of gold dentures might be used for 40 years and porcelain sets would probably have been kept as long as they remained functional. ${ }^{5}$

Examination of the porcelain fabric suggested a French origin was likely (Jacqui Pearce pers. comm.). This does not preclude manufacture in England using a French source of materials, but it is equally likely that Dillon purchased the teeth in France prior to exile.

\section{DISCUSSION}

\section{The social, economic and dietary} implications of dental prostheses

Dillon's dentures are important evidence of a time of immense social change and advancing dental technology. They are important, not only for their place in dental history, but also as a reflection of social and economic circumstances at the end of the eighteenth century. An estimated 150,000 people left France for England between 1789 and $1800,{ }^{33}$ but surprisingly few texts have been published on the émigré clergy in London, ${ }^{13,34}$ in marked contrast to other groups such as the Huguenots.

False teeth were undoubtedly a mark of social standing: Bennison ${ }^{21}$ notes that they were removed at the dinner table with pride (though women would not remove theirs). ${ }^{25}$ There was no 
stigma in the upper echelons of eighteenth century French society attached to wearing false teeth, ${ }^{5}$ and the French presence in eighteenth century dentistry in Britain was considerable enough to be commented on by the satirists of the time. ${ }^{35}$ More than 40 dental practitioners were listed in the directories of London each year in the 1790s and around 25 of those were of foreign origin. ${ }^{8}$ Nicholas de Chemant himself was located at Meards Street, Soho in $1794 .{ }^{9}$ Some of the early immigrant dentists did not advertise, preferring to rely on word of mouth. Those who did, tended to play up, real or fictitious, royal connections. ${ }^{35}$ Records also show a free dental service for émigrés was being operated. ${ }^{13}$

All dentures were expensive, and porcelain more so. In the mid to late eighteenth century, prices of $£ 73$ 10s for a full set of human teeth set in gold and $£ 105$ for a full set of artificial teeth are cited. ${ }^{8}$ The annual wage of a housemaid in the same period was $€ 6-£ 8$ and in 1748 , one could have bought a coach for less than the cost of a set of teeth. ${ }^{3}$ Pearlman ${ }^{20}$ notes the high price of De Chemant's dentures and their apparent quality: in 1804 he charged 60 to 80 guineas a set. The limits of the market for false teeth are apparent: such a purchase reflects the high socioeconomic status of the buyer.

To date, archaeological evidence of dental treatment and artificial teeth has come predominantly from crypt assemblages: the wealthier members of Georgian society. At Spitalfields, those with dental restorations included a barrister, a wealthy silk dyer and the wife of a Consul. ${ }^{36}$

Do the apparent repairs indicate Dillon's later reduced financial circumstances: the émigrés clergy falling on hard times? Dillon's situation certainly changed for the worse in his later years but, as previously mentioned, he was well supported by both the exiled French and the English communities. It is impossible to be certain when or why Dillon lost his teeth. However, his diet would not have been wanting: the northern French clergy shared one fifth of the land in that part of France, as much as the aristocracy and he would have had good access to refined sugars, imported from the French colonies in the West Indies. The teeth were manufactured when the bishop still had some of his own teeth, yet by the time of his death he had lost all of them. This suggests that some time had elapsed since manufacture. What is more, the archbishop either did not feel it was necessary to purchase, or could not locate (or afford) further prosthetics.

It is interesting that no similar examples of porcelain dentures have yet been found archaeologically. Perhaps this is a reflection of differences in fashion and dental technology, between Britain and France and reflects the nature of the population excavated from St Pancras?

\section{A provenance for Dillon's dentures?}

Initial results suggest a French provenance for the dentures is more likely, based on the porcelain fabric and more crudely made English comparisons. From 1800-1801, De Chemant received constant supplies of porcelain paste from Wedgwood with whom he secured exclusive rights for 14 years. ${ }^{5}$ Correspondence between De Chemant and the Wedgwood factory suggests he was not the only person manufacturing porcelain teeth in England in the 1790s. He had attempted to obtain pastes from a Mr Turner, only to be told that he had an agreement with another dentist. ${ }^{24,37}$ De Chemant raised the issue of his patent and felt it was impossible for there to be another dentist manufacturing such teeth. However, a nineteenth century letter from De Chemant's son to another dentist suggests that porcelain teeth were also being manufactured in Dublin during the period..$^{19,20}$ The trade directories show numerous dentists in London at the time, and in 1799 Lesec of Newcastle was charging twice the normal price for his porcelain or 'adamantine' teeth. By 1813 a Joseph Fox was working in association with Wedgwood. Fox and his father before him worked in Clements Lane, London between 1784 and $1800 .^{9}$

Were these French dentures brought to England or an English dentist's copy of the new and foreign technology made for an illustrious French client? If Archbishop Dillon did obtain the dentures in England, Nicholas de Chemant remains a likely contender for manufacturer. ${ }^{9}$ Scientific analysis of the composition of the porcelain could shed light on this by comparing it with the 'recipe' he used, but the uniqueness of this archaeological find means that destructive sampling is not advisable. The museum at Sèvres still holds 158 examples of De Chemant's teeth. It would be interesting to compare this set with those of known provenance, ${ }^{26}$ and so establish more firmly their place in dental history.

\section{Archaeological comparisons}

Nine dentures or bridges were found in the burials from the Crypt of Spitalfields Church including examples made of bone, human teeth in gold, hippopotamus ivory and a nineteenth century example of individual porcelain teeth set into gold. ${ }^{30,36}$ At St. Nicholas's Church Bathampton, upper and lower dentures made from a combination of human and ceramic teeth were found, but these are of a much later date than Dillon's. ${ }^{38}$ Recent work in the crypt of St George's church Bloomsbury and a riversite, KingstonUpon-Thames, revealed sets of porcelain teeth in gold bridgework, again of a later date. ${ }^{39,40}$ At Marylebone Cemetery one set of 'Waterloo' teeth was found. ${ }^{41}$ An early eighteenth century partial denture from Rochester, Kent came from a non-burial context and was carved from ivory. ${ }^{32}$

The British Dental Museum has no similar examples of dental prosthetics, but a visit to the Royal College of Surgeons enabled the examination of several half-dentures of French and English origin. Two examples manufactured by de Chemant in 1796 were unglazed and the third highly glazed. All showed greater detail in the anterior teeth, the molars being represented by blocks. The internal surfaces had been individually moulded to fit and the gums coloured a bright pink. An example of 'Early English Porcelain dentures' was far more crudely carved with crosshatched blocks for molars, although there was an attachment for a spring. In comparison, the 'gums' of Dillon's dentures are much deeper, though perhaps this is a deliberate response to the resorption of the alveolar bone in an elderly individual. Interestingly, one of the examples of De Chemant's teeth had the small puddles of glaze seen in Dillon's set. The quality of Dillon's teeth is clearly finer than the English example, which would support the hypothesis that they were of French manufacture.

\section{CONCLUSIONS}

Dillon's dentures are of high quality porcelain, manufactured in the late-eighteenth century French style, and may have been brought with him on his journey into exile. There is evidence of prolonged use, which encompassed not only cosmetic or vocal functions but also aided mastication. They are unique archaeological artefacts and reflect a pivotal time in dental history, with the adoption of new materials and methods of manufacture. They also represent a period of significant social and economic change for the upper echelons of French society.

Future excavations may recover similar examples of prosthetic work and allow us to paint a more accurate picture of dentistry in Georgian England for, as Hargreaves ${ }^{8}$ states, 'Current knowledge is ... derived predominantly from information given in contemporary printed texts ... rather than from disinterred skeletal material'. Evidence from the excavations at St Pancras goes some way towards redressing this. 
A huge number of people have been involved with this project. Recording of the remains was carried out by the author and Bill White (MoLSS, Specialist Services), James Langthorne, Kathleen Sayer and Don Walker (PCA). The author also wishes to thank: Phillip Emery, Principal Archaeologist who lead the archaeological project, Gifford; Liz Barham, Dr Geoff Egan and Jacqui Pearce of the Museum of London Specialist Services, Sally Brooks Museum Librarian for all her help hunting references; Tiziana Vitali, Kevin Wooldridge (Fieldwork Director) and Hanne Rendall-Wooldridge, of Pre-Construct Archaeology Ltd particularly during post-excavation and the excavation team of Mary-Ellen Crothers, Lindsay Doulton, Vicki Emerson, Stephen Murphy, Gethin Rees, Duncan Sayer, Will Valentine and Dan Waterfall; Rachel Bairsto, Head of Museum Services, British Dental Association Museum; Dom Aidan Bellenger for invaluable research regarding émigrés clergy, Prior, Downside Abbey; Angela Boyle, Head of Burial Archaeology, Oxford Archaeology; Mrs. Lynn Miller from the Wedgwood Museum Information Office; Sarah Pearson of the Royal College of Surgeons; Melvyn Rees of the Patent Office; Trevor Ashwin for editorial comments; Dr Chris Phillpotts for historical advice; Victor Owen for advice on sampling: Helen Glass, Rail Link Engineering; and, of course, London and Continental Railways for funding this work.

1. Molleson T, Cox M, Waldron A H, Whittaker DK. The Spitalfields Project. Volume 2: The Anthropology - The Middling Sort CBA Research Report No 86. 1993

2. Hillam D G. The availability of dental products in Britain at the end of the 18th century. Dental Historian 1997; 32: 56-65.

3. Pickard L. Dr. Johnson's London: coffee houses and climbing boys, medicine, toothpaste and gin, poverty and press-gangs, freak shows and female education. London: Phoenix Press, 2000.

4. Roberts C A, Cox M. Health and disease in Britain: from prehistory to the present day. Stroud: Sutton Publishing Ltd, 2003.

5. Woodforde J. The strange story of false teeth London: Routledge and Kegan Paul, 1968.

6. De Chemant N. A dissertation on artificial teeth: evincing the advantages of teeth made of mineral paste, over every denomination of animal substance. To which is added, advice to mothers and nurses on the prevention and cure of those diseases which attend the first dentition. (4th ed.) London: Dulau and Co, 1804.
7. Bishop M G H, Gelbier S, Gibbons D. Ethics - dentistry and tooth-drawing in the late eighteenth and early nineteenth centuries in England. Evidence of provision at all levels of society. Br Dent J 2001; 191: 575-580.

8. Hargreaves A. Dentistry in the British Isles. In Hillam $C(\mathrm{Ed})$. Dental practice in Europe at the end of the eighteenth century. Clio Medica 72. pp 171-282. New York: Rodopi, 2003.

9. Wright D W. London Dentists in the 18th century: a listing from trades directories in the Guildhall Library. Dental Historian 1986; 12:8-16.

10. Taine H A. The Origins of Contemporary France, Volume 1 - The Ancient Regime. Book 1 Chapter IV Public Services Due by the Privileged Classes. A Project Guttenberg File from Nalanda Digital Library (www.nalanda.nitc.ac.in), 1899.

11. Castle $\mathrm{E}(\mathrm{Ed}$.) The Jerningham Letters (1780-1843): being excerpts from the correspondence and diaries of the Honourable Lady Jerningham and of her daughter Lady Bedingfield. (Richard Bentley and Son: London), 1896.

12. Wilson F M. They came as strangers: The story of refugees to Great Britain. London: Hamish Hamilton, 1959.

13. Bellenger D A. The French exiled clergy in the British Isles after 1789: an historical introduction and working list. Bath: Downside Abbey, 1986.

14. Thornton Col. T. A sporting tour through France in the year 1802. London, 1806.

15. Aston N. Dillon, Arthur Richard (1721-1806) archbishop of Narbonne and émigré leader. Oxford Dictionary of National Biography. Oxford: Oxford University Press, 2004.

16. Rogers J, Waldron T, Dieppe P, Watt I. Arthropathies in Palaeopathology: The Basis of Classification according to Most Probable Cause. J Archaeolog Sci 1987: 14: 179-193.

17. Stroud G, Kemp R L. The medieval Cemeteries of the Church and Priory of St. Andrew Fishergate. The Archaeology of York Volume 12, Fascicule 2. London: Council for British Archaeology, 1993.

18. Aufderheide A C, Rodriguez-Martin C. The Cambridge Encyclopaedia of Human Palaeopathology. Cambridge: Cambridge University Press, 1998.

19. Sugden K C. Nicholas Dubois De Chemant and the disputed invention of false teeth. Br Dent J 1983; 155: 202.

20. Pearlman A. Wedgwood and porcelain dentures. Proceedings of the Wedgwood Society Vol.3. pp 122-125. London: B.T. Batsford Ltd, 1959.

21. Bennison E. Antique dental instruments. London: Sotheby's Publications, 1986.

22. Ring M E. Dentistry: an illustrated history. New York: Harry N. Abrams Ltd, 1985.
23. Patent number GB1803/1791

24. Cohen R A. Messers Wedgwood and porcelain dentures correspondence 1800-1815. BrDent J 1975; 139: 27-31.

25. Woodforde J. The history of vanity. Stroud: Alan Sutton Publishing Ltd, 1992.

26. Kurdyk B. 'Une révolution au début du XIXe siècle: les dents minérales artificielles.' Actes de la Société française d'histoire de l'art dentaire, 1996.

27. Kurdyk B. Nicholas Dubois de Chemant and the use of porcelain in dental art. J Hist Dent 1999; 47: 126-128.

28. Kurdyk B. Guiseppangelo Fonzi: industrial Fabrication Promoter of Porcelain Prosthetics. J Hist Dent 1999; 47: 79-92.

29. Egan G. Unpublished assessment notes.

30. Whittaker D K. Dental Aspects of the Spitalfields Exhumations. Dental Historian 1991; 21: 30-43.

31. Hillam D G. Dental treatment of the early nineteenth century: how effective was it? Dental Historian 1989; 17: 20-33

32. Anderson T, O'Connor S, Ogden A R. An early eighteenth-century denture from Rochester, Kent, England. Antiquity 2004; 78: 858-864.

33. Bindman D. The Shadow of the Guillotine: Britain and the French Revolution. London: British Museum Publications Ltd, 1989.

34. Carpenter K. Refugees of the French revolution: Émigrés in London. Basingstoke, 1999.

35. Hargreaves A. French Practitioners in mid-18th century London. Dental Historian 1992; 22: 21-30.

36. Whittaker D K, Hargreaves A S. Dental restorations and artificial teeth in a Georgian Population. Dental History 1991; 7: 371-376.

37. King R. The history of dentistry: Technique and demand. Cambridge Wellcome Unit Publications, 1997.

38. Cox M, Stock G. Nineteenth century Bath-stone walled graves at St. Nicholas's Church, Bathampton. Proceedings of the Somerset Archaeological and Natural History Society Vol. 138. Stroud: Alan Sutton Publishing Ltd, 1995.

39. Mepham L. Metal objects. (Specialist appendix) In Andrews P, Lowe J, Nichols K. Charter Quay: The spirit of change - The archaeology of Kingston's riverside. pp 1-9. Salisbury: Trust for Wessex Archaeology Ltd, 2003.

40. Greater London Archaeology Advisory Service (GLAAS). London Region Quarterly Review April to June 2003. London: English Heritage, 2003.

41. Werner $A(E d)$. London bodies: the changing shape of Londoners from prehistoric time to the present day. London: Museum of London, 1998. 